\title{
THE ELECTORAL COLLEGE AND PRESIDENTIAL SUFFRAGE.
}

The Constitution of the United States was framed nearly a century and a half ago when government by the people, or even for the people, was an untried experiment. The masses, as a rule, were uneducated and entirely without experience in government, and the propertied class looked upon the idea of entrusting the government to their hands as rash and inexpedient. It had been attempted only in England and there a share in the government was restricted to the nobility in one house and the property owners of means in the other. Even in this country in 1787 , when the United States Constitution was framed, in few states was there manhood suffrage even for the lower house. For the state senates there was required for many years a property qualification for electors. In only one state was the governor elected by the people. In the other states he was chosen by the legislatures and in not one were the people entrusted with the election of the judges. The whole idea was to restrain whatever share in the government was given to the people by every safeguard that could be thought of, which was not too evidently a denial of popular government.

By the federal constitution only one-sixth share in the government, i.e., half of the legislative department, the lower house of Congress, was to be elected by the people and in many states there was a restriction upon suffrage even as to that, for it was provided that the representatives should be chosen by those qualified to vote for members of the lower house of the state legislature, and this did not mean manhood suffrage in all the states at that time.

The United States senators were to be elected at second hand by the state legislatures, and the Senate was by far more important than the House of Representatives because to the Senate was committed the confirmation of the appointees of the president and the treaty-making power. Moreover, the senators were elected for a term of six years while the members of the House had a term of only two years. 
The president was made elective at third hand by electors, who were usually chosen by the state legislature, and it was intended that the electoral body should really be independent electors. In the constitution of 1787 at Philadelphia it was provided that the electors should vote for two persons, the person having the greatest number of votes should be president and that the next highest should be vice-president. Thus it was not contemplated that nominees for president and vice-president should be considered by the legislatures in selecting the electors for president. At the close of Washington's term began the present system of nominating a president and vice-president for whom the electors were expected to vote, but in I8or Thomas Jefferson and Aaron Burr, who had been nominated on the same ticket for president and vice-president, had the same number of votes. This threw the election into the House of Representatives on the competition of Burr for president, and a crisis arose which was only averted by the best statesmanship of the age. Jefferson was finally chosen but to prevent the occurrence of another crisis the twelfth amendment was adopted. Under this, however, the people have practically achieved an amendment to the constitution of the most serious nature but which is not written in the constitution, and that is the president by universal acceptance has been made elective by the people, and the electors have become simply figureheads to express the public will as to the choice of a president.

- The legal election, which takes place when the electors assemble in the several state capitols and vote in January following, passes unnoticed. In law, and under the constitution, any elector is free to vote for whom he chooses. But even in the exciting contest between Tilden and Hayes (when the result was determined by one vote in the electoral college, as counted by Congress) there was not an elector who dared to vote for any other candidate than those named at the head of the ticket on which he himself was elected at the November election. In the first contested election in 1796 , three electors chosen on the Democratic-Republican ticket felt free to vote for John Adams, the Federalist candidate, and thereby defeated Jefferson, who' 
would have been elected if even two of the three had voted for him, for the vote stood Adams seventy-one, Jefferson sixtyeight.

The United States judges were to be selected at fourth hand, by being appointed by a president, elected at third hand and confirmed by a senate elected at second hand, and to make them further entirely independent of that public opinion upon which in theory our form of government rests, these judges were made appointive and given life tenure. By the decision in Marbury v. Madison, ${ }^{1}$ an obiter dictum by the way, these judges gave themselves without any expression in the constitution, the irreviewable power, to be exercised by a majority of their own body, to veto any act of Congress, though approved by the executive department. This enormous power was claimed but not exercised in Marbury v. Madison, which had no immediate effect, for Mr. Jefferson and the Congress of that day would have refused to execute any decision to that effect. This power was not again claimed as against an act of Congress until the Dred Scott case ${ }^{2}$ in 1856 . and that was soon set aside by the result of the great Civil War, but the court has since construed the fourteenth amendment (which was intended solely for the protection of the negroes) as giving the judiciary the power it had before asserted.

The veto given the president was not absolute but was made subject to reversal by a two-thirds vote in Congress. If it had been intended also to give the Supreme Court the veto power, it is very certain that that veto would have been made also subject to reversal by the same vote. If the president or Congress does not properly interpret the constitution, as the people understand it, they can be changed at the end of their short terms, but if the judges exercise the judicial veto, contrary to the popular will, they can not be reversed nor reviewed except by a constitutional amendment as was done by the eleventh amendment and the seventeenth amendment. When the court con-

\footnotetext{
I Cranch 137 (1803).

2 rg How. 393 ( 1856$)$.
} 
ferred on itself the veto power, it did not restrict it as subject to be overruled (like the president's veto) by a two-thirds vote. If there be such unlimited and irreviewable power, the ultimate power in our government is bestowed by the constitution on five appointive life-tenure judges. The grant of so enormous and irresponsible a power should be clear and not left to inference or argument by the claimants of such power. Let the paragraph in the constitution conferring it be pointed out and all controversy will be at an end. If such unrestricted-negative upon the action of the two houses of Congress approved by the president, existed, it would practically amount to bestowing upon five appointive life-tenure judges the power that the English have but recently taken from their House of Lords as unendurable. It would also result that whatever influence could secure the appointment of five out of nine judges on the United States Supreme Court could in truth say to the people of this country, as has been claimed, "Thus far shalt thou go, and no further." This power is so enormous and so contrary to the genius of a government based upon the popular will that it can not be accepted unless written in unmistakable words in the face of the constitution.

Returning to the electoral college, the present cumbersome system under which, as in the last election, the result in the union may be decided by a very few votes in the ballot box, as in North Dakota, in New Hampshire, or California-or as in South Carolina, Florida, Louisiana, or Oregon in the HayesTilden election-has always been pregnant with danger.

The Constitution of the United States, Article II, clause 2, provides: "Each state shall appoint in such manner as the legislature thereof may direct a number of electors equal to the whole number of senators and representatives to which the state may be entitled in the Congress." The legislature of each state, of course, is elected in the manner prescribed by its constitution, but the power and discretion vested in it to provide the manner in which the presidential electors shall be chosen is derived solely from the Constitution of the United States, and no state. constitution can restrict the execution of such power. The 
federal constitution selected a state agency as the depositary of this power, but the exercise of such power is given to the state legislature subject to no restriction from the state constitution.

In $M c$ Pherson v. Blacker, ${ }^{3}$ Chief Justice Fuller quotes with approval the following from the Report of the Senate Committee on Privileges and Elections by Senator Morton, its chairman:

"The appointment of these electors is thus placed absolutely and wholly with the legislatures of the several states. They may be chosen by the legislature, or the legislature may provide that they shall be elected by the people of the state at large, or in districts, as are members of Congress, which was the case formerly in many states; and it is, no doubt, competent for the legislature to authorize the governor, or the supreme court of the state, or any other agent of its will, to appoint these electors. This power is conferred upon the legislatures of the states by the Constitution of the United States, and can not be taken from them or modified by their state constitutions any more than can their power to elect senators of the United States. Wherever provisions may be made by statute, or by the state constitution to choose electors by the people, there is no doubt of the right of the legislature to resume the power at any time, for it can neither be taken away nor abdicated."

The court (on p. 36) added: "The construction to which we have referred has prevailed too long and been too uniform to justify us in interpreting the language of the Constitution as conveying any other meaning than that heretofore ascribed, and it must be treated as decisive."

It is a federal power which the state legislatures have exercised at will, and in divers ways, and have changed the method from time to time, as suited them. At the first election for president in 1789 all the states (North Carolina, Rhode Island and New York not voting) chose the electors by their legislatures, except Virginia, which chose them by districts in 1789I796. That state chose them by the state at large in 1800 and I804; it then returned to the district plan in $1808-1816$. It elected them by general ticket in 1820 and 1824 , then by districts in 1828 , and then again in $183^{2}$ it returned to the plan

" 46 U. S. I, 34 (1892). 
of electing them by the state at large, which policy it has pursued ever since.

The other states also show changes between these three methods from time to time, although since I824 most of the states have elected by the state at large. South Carolina, however, persisted in electing by the legislature until after the war. Florida chose its electors by the legislature in I868 and Colorado did the same in 1876 .

In 1789 New York, though (unlike North Carolina and Rhode Island) already in the union, failed to participate in the presidential election and chose no electors. North Carolina and Rhode Island chose no electors that year because they had not at the time entered the union. Nor were the above three methods of election-by the legislature, by general ticket or by districtsthe only methods which the legislatures have adopted. The Supreme Court of the United States in McPherson v. Blacker, has pointed out that in Tennessee and North Carolina the legislatures at one time committed the choice of electors to a limited number of citizens, not representing the state in any other public function.

In North Carolina in 1796 , the legislature passed an act dividing the state into four districts, and directed that the members of the legislature residing in each district should meet on a certain day and choose three electors. In Tennessee in 1796 , and in 1800 , the legislature appointed certain persons by name, in-each of three districts, which should choose an elector for each of the three districts. In some states, at times, it was directed that each congressional district should choose an elector and that the two electors at large should be chosen by the whole state, and in other states the two electors at large have been chosen by the legislature although the other electors were chosen by the people by districts.

The power of the legislature of each state to exercise its discretion in the method of choosing electors is plenary and has been exercised in the above method and in still other ways. In

- Ubi supra, at 29-32. 
Maryland in 1788 the electors were chosen by a general ticket, but were allotted three to the western shore and two to the eastern shore of that state. In the second presidential election the electors were chosen in nine states by the legislatures, and in six by the people. Of these latter, Maryland, New Hampshire and Pennsylvania chose their electors by a general ticket, and Virginia by districts. In Massachusetts the state was divided into four districts, in each of two of which five electors were chosen, and in each of the other two, three electors. In North Carolina, as above stated, the legislature divided the state into four districts and directed that the members of the legislature residing in those districts should choose three electors for each district.

In Illinois by the Act of June, I9I3, the General Assembly by a majority vote (by one majority in the state senate) directed, in execution of the trust confided to it by the federal constitution, that the twenty-nine electors from that state should be chosen at the ballot box by the adult citizens of that state, not disqualified for crime, irrespective of sex. At the election on November 6, I9I6,876,700 women participated in the choice of electors. The twenty-nine electors thus chosen were duly counted by the two houses of Congress in canvassing the votes for president. This is the ultimate tribunal to pass upon the legality of the electoral vote. So the matter is thus settled in accordance with the unbroken precedents in the past, that the electors for any state shall be chosen, in the language of the federal constitution, "in such manner as the legislature thereof may direct." These legislatures have "directed" in many and divers manners as above set forth. Recently in North Dakota and Rhode Island with five electoral votes each; in Nebraska with eight votes; in Arkansas (in the primary) with nine votes; in Indiana and Michigan with fifteen each, and in Ohio with twenty-four, statutes similar to that in Illinois have been adopted providing that women may vote for presidential electors in the same manner as men. In all eight of these states suffrage for officers named in the state constitution is restricted to "male persons," though in several of them the legislature has conferred equal suffrage for municipal and county elections. There are eleven other states in which, un- 
der their constitutions, women exercise full suffrage and undẹr the direction of the legislatures, which prescribe that the presidential electors shall be chosen "by the duly qualified voters," women vote equally with men. Thus in nineteen states casting one hundred and seventy-two electoral votes and with over eight and a half million women voters, the electors are now chosen by equal suffrage. The legislatures in many other states will probably take the same action of conferring presidential suffrage on women.

The usual method for many years has finally settled down to the choice of presidential electors at the ballot box and by the state at large in every state. This was first done by the large states as it gave them more power and influence in the change of administration than voting by the district method, but the plan has since become general. This system is highly objectionable in many respects. Among other reasons, it readily lends itself to the choice of a minority candidate for president, which has happened no less than nine times. John Quincy Adams in 1824 , Hayes in 1876 , Harrison in 1888 received fewer votes in the ballot box than their opponents. Polk, Taylor, Buchanan, Lincoln (in 186I) Garfield and Cleveland (in 1892 ), each received fewer popular votes than the combined opposition. The chief objection, however, to the method of election by a general ticket in each state is the suppression of minorities. For instance, in New York in I884 a change of five hundred fifty-six votes cast at the ballot box would have given the thirty-six electoral votes of that state to Blaine instead of to Cleveland, thus determining the result in the union, making as it would a change of seventy-two electoral votes. In all justice eighteen votes should have been given to each.

It is an anomaly that I,Iro votes in New York (as in I884) should swing seventy-two electoral votes, thirty-six from one candidate to the other and thus decide the result. The consequence is that while, nominally, any citizen of the republic is eligible to the presidency, only citizens of two or three of the larger states, with doubtful electoral votes, are in fact eligible. All others are barred. For proof of this look at the history of our presidential elections. For the first forty years of the union 
the presidents came from two states-Virginia and Massachusetts. Then there followed a period when the growing west requiring recognition, Tennessee, Ohio and New York commanded the situation for the next sixteen years. The Mexican War gave us a soldier who practically represented no state, and was succeeded, on his death, by a New Yorker. Then for the only time in our history "off states" had a showing and Pennsylvania and New Hampshire had their innings. Since then the successful candidates (except the present incumbent) have been strictly limited to "pivotal states"-New York in the East and Illinois, Indiana and Ohio in the West. This condition is unsatisfactory. The magnetic Blaine from Maine was defeated, as was Bryan from Nebraska. Had the former haled from New York or the latter from Illinois the electoral votes and influence of those states might have secured their election.

In view of these and other objections it has been long and strenuously urged that the states return to the system which all have now abandoned, of choosing the electors by districts. This would require a constitutional amendment, however, as it would be an interference with the discretion reposed in the legislature of each state to appoint the electors "in such manner as the legislature thereof may direct." It would be equally objectionable as the present system in that there would inevitably result a competition in gerrymandering.

Another method that has been often urged is to change the election of president by abolishing the electoral college and choosing the president by a per capita vote of the whole union. To do the last would be dangerous and almost a certain provocation of civil war, for the charge of fraudulent voting at any precinct or voting place, however remote, might affect the result, and as frauds would most likely occur in those states where the majorities are largest, as in Pennsylvania or Texas, Ohio or Georgia, a contest would always be certain, and federal supervision of every voting precinct throughout the union would be necessary, whereas now frauds in states giving large majorities, unless of great enough magnitude to change the electoral vote of the whole state, can have no effect. Besides, it would be impossible to get the change enacted by the required two- 
thirds vote in Congress or ratified by the three-fourths of the states, for the smaller states would not give up the "loading" of their vote now afforded by the two electoral votes allowed each state, irrespective of size, and the South especially would not consent to a system which would deprive them of representation by reason of the negroes and the women not voting at the ballot box.

Under the present system each state has representation according to its census population, plus two votes to each statethat is, the electoral vote of each state equals the number of federal representatives and senators; but if in a presidential election the electoral vote is based upon the number of ballots actually cast, would the smaller states assent to the loss of the two electoral votes given for statehood, which are now half the electoral vote in several states? Would the South ratify an amendment to elect a president on that basis, when, as a rule, the negroes do not vote and the country from Delaware to the Rio Grande would lose at once one-third of its power in the election of president? Would any of the southern states, or others, do that which would cost one-half of their remaining votes where the women do not vote as compared with the states where they do vote?

If the South lost one-third of its weight in a presidential election by the negroes not voting and one-half of its remaining strength by the women not voting, it would not have any more power in the election of a president than the single State of New York which would cast more ballots than the whole South when the women vote in that state, as they probably. will at the next presidential election. Is the adoption of a constitutional amendment bringing about a percapita vote for president throughout the union capable of adoption, or will it be wise in view of the danger of a contest over the returns of every voting precinct?

May the writer suggest that the remedy is, while abolishing the electoral college, to preserve the system of giving each state the same number of electoral votes as now? This is equivalent to the French system of electing the president in a joint session of the two houses of their Parliament, only our election will be by the people. But instead of giving the entire 
vote of any state to the candidate that gets a small majority therein, as when a majority of $\mathrm{I}, \mathrm{I}$ IO at the polls swung the entire thirty-six electoral votes of New York from Blaine to Cleveland, or the sixty-three ballots which changed the four electoral votes of New Hampshire to Mr. Wilson, or the two hundred ninety-four ballots which gave the entire twelve votes of Minnesota to Mr. Hughes (either of which states might have changed the entire election), the electoral vote of each state should be divided according to the popular vote in that state for each candidate without any fractions. Thus, Mr. Cleveland should have got eighteen and Mr. Blaine eighteen. Other states would be divided more or less evenly and the result would be that the choice of president would no longer be restricted to two or three states, as was the case for long periods in our past history and is likely to be always the case as long as- the whole electoral vote of two or three large pivotal states must swins: to one side or the other and determine the result. $A$ close ballot in any state would then not affect more than one electoral vote.

This is substantially the suggestion made years ago by Senator Buckalew of Pennsylvania except that he added (which is advisable) the abolition of the cumbersome and useless electoral college and the certification by the state boards' of elections of the popular vote to be counted by Congress on the above stated basis.

This change would avoid also the present evil of large sums being spent to carry the solid electoral vote of pivotal states, for they would cease to be pivotal states. At the same time, this would avoid the open gulf into which a per capita ballot by the whole union would lead us. While the electoral vote of a state should be divided pro rata, according to the popular vote for each candidate, it is essential that each state should vote as one district, since its boundaries are unchangeable. To permit the legislature of each state to divide it into electoral districts would, as already stated, simply open up competition in the art of gerrymandering.

Supreme Court,

Walter Clark.

Raleigh, N.C. 